\title{
FAKTOR-FAKTORYANG MEMPENGARUHI KESEJAHTERAAN HIDUP MASYARAKAT SUKU LAUT PULAU BERTAM KOTA BATAM
}

\author{
Meri Enita Puspita Sari' ${ }^{1}$, Diah Ayu Pratiwi² \\ ${ }^{1}$ Program Studi Ilmu Pemerintahan, Fakultas Ilmu Sosial dan Ilmu Politik, Universitas Riau Kepulauan, \\ Indonesia \\ puspita.meri@yahoo.co.id \\ 2Program Studi Ilmu Pemerintahan, Fakultas Ilmu Sosial dan Ilmu Politik, Universitas Riau Kepulauan, \\ Indonesia \\ diah_mahdan@yahoo.co.id
}

\begin{abstract}
Abstrak
Pemerintah Kota Batam telah melaksanakan berbagai usaha untuk meningkatkan kesejahteraan hidup dikalangan komunitas suku laut. Berbagai program, pelatihan dan pendidikan keterampilan telah dilakukan oleh pemerintah kepada Suku Laut ini untuk meningkatkan keterampilan dasar mereka, namun program-program yang dilaksanakan masih belum mampu meningkatkan keterampilanketerampilan dasar yang diperlukan dalam kehidupan Suku Laut. Penelitian ini menggunakan metode penelitian kualitatif, metode ini digunakan untuk dapat menggambarakan dan mengkaji faktor-faktor yang mempengaruhi tingkat kesejahteraan masyarakat suku laut Pulau Bertam. Berdasarakan hasil penelitian, Perubahan hidup yang dijalankan oleh masyarakat suku laut pulau Bertam mempengaruhi kualitas hidup mereka terutama kesejahteraan sosial. komunitas Suku Laut masih bergantung kepada hasil tangkapan ikan secara tradisional saja dan hidup dalam kondisi yang serba kekurangan, hal tersebut terlihat dari kualitas air yang diperoleh, rumah yang ditempati dan peralatan tangkapan ikan yang belum memadai, diaspek sosial lainnya komunitas masyarakat Suku Laut didapati masih tidak melakukan aktivitas kemasyarakatan secara bersama antara satu sama lain. Selain faktor agama yang berbeda, masyarakat lebih banyak berkumpul dengan keluarga masing-masing dibanding berbaur dengan masyarakat lainnya yang lain. Aspek budaya juga mempengaruhi perubahan hidup masyarakat Suku laut. Hal ini terlihat dari mulai pudarnya budaya tradisi dalam hal kesenian dan generasi yang ada akan berhadapan dengan beberapa ancaman seperti kehilangan identitas Suku Laut sebagai penangkap ikan, kesulitan meneruskan kehidupan karana masyarakat mereka masih berada dalam tingkat pendidikan yang sangat rendah dan tidak mampu bersaing dalam dunia yang semakin berkembang.

Kata Kunci : Kesejahteraan Masyarakat, Masyarakat Suku Laut, Peranan Pemerintah.
\end{abstract}

\begin{abstract}
The Batam City Government has carried out various efforts to improve the welfare of life among the tribal communities. Various programs, training and education skills have been carried out by the government to the Sea Tribe to improve their basic skills, but the programs implemented have not been able to improve the basic skills needed in the life of the Sea Tribe. This study uses qualitative research methods, this method is used to be able to draw and examine the factors that influence the level of welfare of Bertam Island tribal people. Based on the results of the study, changes in life carried out by the marine tribes of Bertam Island affect their quality of life, especially social welfare. The Sea Tribe community still relies on traditional fish catches only and lives in deprived conditions, it can be seen from the quality of water obtained, houses occupied and inadequate fish catching equipment, other social aspects Sea communities are found not do community activities together with each other. In addition to different religious factors, people gather more with their families than they mingle with other communities. The cultural aspect also influences changes in the life of the sea tribe community. This can be seen from the beginning of the fading culture of tradition in terms of art and the existing generation will be faced with several threats such as loss of identity of the Sea Tribe as fishers, difficulties in continuing their lives because their society is still at a very low level of education and unable to compete in a world that growing.

Keywords: Public Welfare, Marine tribe society, The role of government.
\end{abstract}




\section{PENDAHULUAN}

Kesejahteraan hidup merupakan satu proses dinamik yang memberi nilai kepada manusia tentang bagaimana kehidupan mereka berubah dan bertambah baik atau sebaliknya. Kualitas hidup rakyat yang bertambah baik menunjukkan kesejahteraan rakyat meningkat dan maju. Banyak indikator yang bisa digunakan untuk mengukur kesejahteraan hidup masyarakat, ini karena konsep kesejahteraan hidup itu sendiri bersifat subjektif dan susah diukur, lebih lagi dalam sebuah negara yang mempunyai pelbagai bidang ekonomi sebagi penyumbang pendapatan negara seperti sektor perindustrian, perikanan dan perdagangan.

Tidak bisa dipungkiri, Indonesia juga mengambil bagian dalam usaha menuju negara maju. Perkembangan pesat Indonesia dalam beberapa industri seperti manufaktur dan pariwisata menyebabkan tahap kesejahteraan rakyat Indonesia juga semakin bertambah. Menuju masa depan, Indonesia yang memiliki populasi keempat terbesar didunia ini berharap agar semua penduduknya dapat mencapai kesejahteraan hidup.

Kota Batam merupakan kota terbesar di Provinsi Kepulauan Riau, Wilayah administrasi di Pulau Batam, tidak hanya memfokus kepada Kota Batam saja, tapi mencakupi beberapa pulau lain yang berdekatan yaitu Pulau Galang dan Pulau Rempang. Pulau Batam lebih kepada konsep perkotaan dan perindustrian sedangkan Pulau Galang dan Pulau rempang lebih kearah desa dan perkampungan. Posisi Pulau Batam yang sangat strategis di rute perdagangan antar negara menyebabkan pihak pemerintah menjadikan Pulau Batam, Pulau Rempang dan Pulau Galang adalah kawasan bebas pajak. Sehingga berdampak pada pertumbuhan fizikal dan sosial ekonomi Kota Batam.

Pertumbuhan yang terjadi di Kota Batam menyebabkan perubahan pada Kota Batam termasuk di kecamatan Belakang Padang. Belakang padang merupakan kecamatan pertama dan tertua dalam pemerintahan Kota Batam. Terdapat dua potensi unik yang ada di kecamatan Belakang Padang yaitu potensi berbentuk fisik dan potensi non fisik. Potensi berbentuk fisik lebih kepada akses perjalanan yang mudah dan cepat dari Pulau Batam, infarstruktur darat yang mencukupi, memiliki sumber dalam yang indah untuk sektor pariwisata dan pemandangan yang cantik karena dikelililingi air laut. Sedangkan potensi bukan fisik merujuk kepada karakter masyarakat Suku laut yang heterogen yaitu sebagian besarnya adalah nelayan dan selebihnya bercocok tanam dan berdagang makanan.

Banyaknya investor yang masuk menyebabkan kawasan perindustrian di Kota Batam semakin meluas dan berdampak terhadap peningkatan jumlah konstruksi bangunan. 
Peningktan jumlah bangunan perindustrian seperti kilang dan gedung perniagaan menyebabkan banyak masuknya pekerja asing di Kota Batam dalam bidang konstruksi, hal tersebut menyebabkan penduduk asli Kota Batam terpinggirkan dan tidak berpeluang untuk mendapatkan peluang pekerjaan terutama dalam sektor konstruksi karena tingkat pendidikan yang rendah. Selain itu, kekurangan pengetahuan dan keterampilan dalam bidang-bidang yang dibutuhkan menyebabkan penduduk asli tidak mampu memenuhi kebutuhan dan dan kemauan pimpinan dan juga pariwisata. Bukan hanya terjadi dengan penduduk asli Kota Batam, tapi kondisi ini juga terjadi di seluruh kelurahan di bawah kecamatan Belakang padang termasuk kelurahan Kasu dan Pulau Bertam.

Kelurahan Kasu mempunyai luas $186.197 \mathrm{~km}^{2}$ dan 3628 populasi penduduk Suku laut yaitu komunitas yang hidup mengembara di laut (Direktorat Bina masyarakat Terasing depsos RI, 1998). Dari jumlah tersebut, sebanyak 26,9 \% merupakan keluarga nelayan miskin. Saat ini, masyarakat suku laut banyak bermukim secara permanen di Pulau Bertam. Hidup secara permanen menyebabkan adanya perubahan hidup yang dijalani yang tentu saja berbeda dengan kehidupan sebelumnya sebagai pengembara di perairan sekitar Batam.

Masyarakat suku laut yang sebagian besar merupakan keluarga nelayan, kehidupan dan penghidupan nelayan tergantung dari hasil laut. Kenyataannya menyebutkan bahwa laut sukar mereka duga, menyebabkan jumlah penghasilan mereka pun tidak mampu mereka duga. Kehidupan suku laut selalu diungkapkan dengan keterbelakangan baik dari segi mata pencaharian maupun cara berpikir dan sikap yang masih tradisional. Hal ini tentu saja akan berpengaruh terhadap tingkat kesejahteraan masyakat suku laut.

Guna meningkatkan kesejahteraan masyarakat, terutama masyarakat suku laut Pemerintah Kota Batam telah melaksanakan berbagai usaha untuk meningkatkan kesejahteraan hidup dikalangan komunitas suku laut. Program yang pernah dilakukan dengan 2 model yaitu model kebijakan pemberdayaan langsung oleh pemerintah dan model kebijakan pemberdayaan mandiri yang dilaksanakan oleh swasta. berbagai program, pelatihan dan pendidikan keterampilan telah dilakukan oleh pemerintah kepada Suku Laut ini untuk meningkatkan keterampilan dasar mereka, namun program-program yang dilaksanakan masih belum mampu meningkatkan keterampilan-keterampilan dasar yang diperlukan dalam kehidupan Suku Laut. Dampaknya, komunitas Suku Laut masih bergantung kepada hasil tangkapan ikan secara tradisional saja dan hidup dalam kondisi yang serba kekurangan. Dampak ke depan, generasi komunitas ini akan berhadapan dengan beberapa ancaman seperti 
kehilangan identitas Suku Laut sebagai penangkap ikan, kesulitan meneruskan kehidupan karana masyarakat masih berada dalam tingkat pendidikan yang sangat rendah dan tidak mampu bersaing dalam dunia yang semakin maju.

\section{DASAR PEMIKIRAN}

\section{Kesejahteraan Hidup}

Berbagai definisi kesejahteraan hidup telah dikemukaan oleh peneliti-peneliti sebelumnya. Definisi secara umum, kesejahteraan hidup merupakan suatu siklus yang melibatkan beberapa perubahan aspek dasar kehidupan manusia yang tidak meningkat terhadap suatu keadaan yang lebih baik dalam kelompok masyarakat, gaya hidup dan hubungan sosial. Menurut Magrabi et al. (1991), kesejahteraan didefinisikan sebagai suatu keadaan yang sehat, nyaman dan senang dari konsumsi barang dan pelayanan.

Menurut Undang-undang Republik Indonesia Nomor 11 tahun 2009, kesejahteraan Sosial adalah kondisi terpenuhinya kebutuhan material, spiritual, dan sosial warga negara agar dapat hidup layak dan mampu mengembangkan diri, sehingga dapat melaksanakan fungsi sosialnya, dan penyelenggaraan kesejahteraan sosial adalah upaya yang terarah, terpadu, dan berkelanjutan yang dilakukan Pemerintah, pemerintah daerah, dan masyarakat dalam bentuk pelayanan sosial guna memenuhi kebutuhan dasar setiap warga negara, yang meliputi rehabilitasi sosial, jaminan sosial, pemberdayaan sosial, dan perlindungan sosial. Dimana dalam penyelanggaraannya dilakukan atas dasar kesetiakawanan, keadilan, kemanfaatan, keterpaduan, kemitraan, keterbukaan, akuntabilitas,partisipasi, profesionalitas dan keberlanjutan.

Lalu menurut Zastrow (2000) kesejahteraan sosial adalah sebuah sistem yang meliputi program dan pelayanan yang membantu orang agar dapat memenuhi kebutuhan sosial, ekonomi, pendidikan dan kesehatan yang sangat mendasar untuk kesejahteraan masyarakat. Dalam PBB, kesejahteraan sosial adalah kegiatan-kegiatan yang terorganisasi yang betujuan untuk membantu individu atau masyarakat guna memenuhi kebutuhan-kebutuhan dasarnya dan meningkatkan kesejahteraan selaras dengan kepentingan keluarga dan masyarakat. Selanjutnya kesejahtaraan masyarakat adalah suatu kondisi yang memperlihatkan tentang keadaan kehidupan masyarakat yang dapat dilihat dari standar kehidupan masyarakat (Badrudin, 2012). 
Terdapat berbagai perkembangan pengukuran tingkat kesejahteraan dari sisi fisik, seperti Human Development Index (Indeks Pembangunan Manusia), Physical Quality Life Index (Indeks Mutu Hidup), Basic Needs (Kebutuhan Dasar), dan GNP/Kapita (Pendapatan Perkapita). Ukuran kesejahteraan ekonomi inipun bisa dilihat dari dua sisi, yaitu konsumsi dan produksi (skala usaha). Dari sisi konsumsi maka kesejahteraan bisa diukur dengan cara menghitung seberapa besar pengeluaran yang dilakukan seseorang atau sebuah keluarga untuk kebutuhan sandang, pangan, papan, serta kebutuhan lainnya dalam waktu atau periode tertentu.

\section{Kesejahteraan Hidup Sosial dan Ekonomi}

Kesejahteraan sosial meliputi aspek perumahan, hubungan sosial, administrasi, keamanan, keterlibatan sosial, kebudayaan, keseahtan, lingkungan dan keluarga. Menurut Embong (2005), UNDP telah memperkenalkan tiga konsep pembangunan yang meliputi perwujudan kesejahteraan hidup komunitas yaitu : (1). Pekerjaan dan pendapatan, (2) pendapatan, (3) kesehatan. Namun begitu, ketiga- tiganya indikator ini dianggap belum cukup kuat untuk membangun suatu kesejahteraan hidup.

Perubahan ekonomi suatu masyarakat bisa diukur melalui pendapatan perkapita, daya beli, peningkatan konsumsi, jumlah modal, penyediaan kemudahan transportasi, biaya, jumlah tabungan dan perbelanjaan serta perdagangan. Hasil penelitian Ardiansyah (2005) yang berjudul Pelaksanaan program Budaya Ekonomi Pesisir di Kota Pangkal Pinang menunjukkan bahwa pelaksanaan program bisnis ekonomi dapat meningkatkan pengeluaran, penggunaan teknologi, peluang pekerjaan dan peningkatan pendapatan. Antara faktor yang mempengaruhi keberhasilan pelaksanaan adalah peranan pihak pemerintah, sumber ekonomi, sikap masyarakat dan alat komunikasi (Ardiasnyah, 2005 ; Tuti Murty, 2005).

Kesejahteraan adalah salah satu aspek yang cukup penting untuk menjaga dan membina terjadinya stabilitas sosial dan ekonomi.kondisi tersebut juga diperlukan untuk meminimalkan terjadinya kecemburuan sosial dalam masyarakat. Selanjutnya percepatan pertumbuhan ekonpomi masyarakat memerlukan kebijakan ekonomi atau peranan pemerintah dalam mengatur perekonomian sebagai upaya menjaga stabilitas perekonomian.

Ekonomi Italia, Vilveredo Pareto, telah menspesifikasikan suatu kondisi atau syarat terciptanya alokasi sumberdaya secara efisien atau optimal, yang kemudian terkenal dengan istilah syarat atau kondisi pareto (Pareto Condition). Kondisi pareto adalah suatu alokasi barang sedemikian rupa, sehingga bila dibandingkan dengan alokasi lainnya, alokasi tersebut 
takan merugikan pihak manapun dan salah satu pihak pasti diuntungkan. Atas kondisi pareto juga bisa didefinisikan sebagai suatu situasi dimana sebagian atau semua pihak individu takan mungkin lagi diuntungkan oleh pertukaran sukarela.

Berdasarkan kondisi pareto inilah, kesejahteraan sosial (sosial welfare) diartikan sebagai kelanjutan pemikiran yang lebih utama dari konsep-konsep tentang kemakmuran (walfare economics), (Swasono, 2005:2). Boulding dalam Swasono mengatakan bahwa "pendekatan yang memperkukuh konsepsi yang telah dikenal sebagai sosial optimum yaitu paretion optimum (optimalitas ala Pareto dan Edeworth), dimana efesiensi ekonomi mencapai sosial optimum bila tidak seorangpun bisa lagi menjadi lebih beruntung.

Teori kesejahteraan secara umum dapat diklasifikasi menjadi tiga macam, yaitu classical utilitarian, neoclassical welfare theory dan new contractarian approach (Albert dan Hahnel dalam Darussalam 2005:77). Pendekatan classical utillatarial menekankan bahwa kesenangan (pleasur) atau kepuasan (utility) seseoarang dapat diukur dan bertambah. Berdasarkan pada beberapa pandangan diatas dapat disimpulkan bahwa tingkat kesejahteraan seseorang dapat terkait dengan tingkat kepuasan (utility) dan kesenangan (pleasure) yang dapat diraih dalam kehidupannya guna mencapai tingkat kesejahteraannya yang diinginkan. Maka dibutuhkan suatu prilaku yang dapat memaksimalkan tingkat kepuasa sesuai dengan sumberdaya yang tersedia.

Kesejahteraan hidup seseorang dalam realitanya, memiliki banyak indikator keberhasilan yang dapat diukur. Dalam hal ini Thomas dkk. (2005:15) menyampaikan bahwa kesejahteraan masyarakat menengah ke bawah dapat di representasikan dari tingkat hidup masyarakat ditandai oleh terentaskannya kemiskinan, tingkat kesehatan yang lebih baik, perolehan tingkat pendidikan yang lebih tinggi, dan peningkatan produktivitas masyarakat. Kesemuanya itu merupakan cerminan dari peningkatan tingkat pendapatan masyarakat golongan menengah kebawah. Todaro secara lebih spesifik mengemukakan bahwa fungsi kesejahteraan $\mathrm{W}$ (walfare) dengan persamaan sebagai berikut :

$\mathrm{W}=\mathrm{W}(\mathrm{Y}, \mathrm{I}, \mathrm{P})$ Dimana $\mathrm{Y}$ adalah pendapatan perkapital I adalah ketimpangan, dan P adalah kemiskinan absolute. Ketiga fariabel ini mempunyai signifikan yang berbeda-beda, dan selayaknya harus dipertimbangkan secara menyeluruh untuk menilai kesejahteraan di Negara-negara berkembang. Berkaitan dengan fungsi persamaan kesejahteraan diatas, diasumsikan bahwa kesejahteraan sosial berhubungan positif dengan pendapatan perkapital, namun berhubungan negative dengan kemiskinan. 
Dalam teori ekonomi mikro ada yang dikenal dengan teori Pareto yang menjelaskan tentang tiga jenis tingkatan kesejahteraan, yaitu pertama pareto optimal. Dalam tingkatan pareto optimal terjadinya peningkatan kesejahteraan seseorang atau kelompok pasti akan mengurangi kesejahteraan orang atau kelompok lain. Kedua, pareto non optimal. Dalam kondisi pareto non-optimal terjadinya kesejahteraan seseorang tidak akan mengurangi kesejahteraan orang lain. Ketiga, pareto superior. Dalam kondisi pareto superior terjadinya peningkatan kesejahteraan seseorang tidak akan mengurangi kesejahteraan tertinggi dari orang lain. Menurut teori pareto tersebut, ketika kondisi kesejahteraan masyarakat sudah mencapai pada kondisi pareto optimal maka tidak ada lagi kebijakan pemerintah yang dapat dilakukan.

\section{Peranan Pemerintah}

Membicarakan Kebijakan Pemerintah tentu tidak terlepas dari apa sebenarnya peran pemerintah yang diamanatkan negara untuk rakyatnya. Pemerintah adalah instrumen negara yang ditugaskan untuk melaksanakan Pemerintahan sesuai dengan Konstitusi Negara. Maka itu "pemerintah" disebut juga sebagai Penyelenggara negara dan harus mengawal dan melaksanakan idiologi negara. Idiologi negara Indonesia adalah tentu mewujudkan Negara Kesejahteraan (Welfare State) sebagaimana tercantum dalam Pembukaan UUD 1945 khususnya yang menyangkut masalah tujuan negara Indonesia, pada intinya dapat dirumuskan sebagai " memajukan kesejahteraan umum dan mencerdaskan kehidupan bangsa yang didasarkan pada prinsip keadilan sosial bagi seluruh rakyat Indonesia”.

Tujuan yang dimuat di dalam pembukaan tersebut kemudian di dalam batang tubuh UUD 1945 dituangkan dalam berbagai ketentuan yang menyangkut kesejahteraan rakyat. Tugas utama pemerintah sebagai penyelenggara negara, setidak-tidaknya ada tiga hal yaitu: pertama, sebagai administrator pemerintahan; kedua, sebagai administrator pembangunan dan ketiga, sebagai administrator kemasyarakatan. Diharapkan dengan tugas utama tersebut, maka upaya mewujudkan kesejahteraan dimaksud diselenggarakan dengan sistem pemerintahan yang baik, pembangunan dilaksanakan dengan tertib, prosedural, jujur, adil, efektif, efisien, dan dengan mengajak dan berperan sertanya masyarakat secara luas.

Agar penyelenggaraan pemerintah dapat dilaksanakan dengan baik menurut Kavin Dayoh ada 9 karakteristik dan 9 azas yang perlu dijadikaan rujukan. 9 karakeristik tersebut adalah, pertama, partisipasi masyarakat; kedua, aturan hukum; ketiga, transparansi; keempat, sikap responsif; kelima, berorientasi pada consensus; keenam, kesetaraan/kesederajatan; 
ketujuh, efektifitas dan effisien; kedelapan, akuntabilitas; kesembilan, visi strategis; dan adapun kesembilan azas dimaksud adalah, pertama, asas kepastian hukum; kedua, asas tertib penyelenggaraan negara; ketiga, asas kepentingan umum; keempat, asas keterbukaan; kelima, proporsionalitas; keenam, asas profesionalitas; ketujuh, asas akuntabilitas; asa efisiensi dan kesembilan asas efektifitas.

Peran adalah laku; hal berlaku/bertindak; pemeran; pelaku; pemain (film/drama). 8 Selain itu juga mempunyai sinonim kata seperti kedudukan, tugas, karakter, kontribusi, perwatakan.9 Dalam tinjauan organisasi, peran merupakan komponen dari sistem organisasi yang merupakan perilaku kerja yang dapat menghasilkan beberapa perubahan. 10 Jadi dapat disimpulkan bahwa peran merupakan suatu tindakan yang memberikan kontribusi yang dapat menghasilkan beberapa perubahan. Definisi tersebut sangat relevan dengan pemerintah daerah yang memiliki peran dalam meningkatkan fungsi pasar tradisional dalam mendorong berkembangnya kegiatan perekonomian masyarakat.

Pemerintah memiliki peranan penting dalam meningkatkan kesejahteraan hidup nelayan. Aoron hatcher (2000) memfokuskan kepada pemberian subsidi secara langsung seperti metode menangkap ikan, subsidi pelatihan peralatan baru dan perbaikan perahuperahu nelayan dan hasil kajian mendapati bahwa dana publik tersebut mampu meningkatkan tingkat keseajhteraan hidup nelayan. Pemerintah perlu memainkan peranan yang sangat penting dalam pembentukan dan pelaksanaan dasar sosial dan pelayanan sosial. Melalui strategi dasar sosial, pemerintah bertanggungjawab untuk memperhitungkan setiap aspek masalah sosial yang terjadi dalam kelompok, dimana melalui strategi pelayanan sosial, pemerintah mempunyai tangguangjawab untuk menyelesaikan msalah sosial sesuai dengan Undang-undang yang berlaku.

\section{PEMBAHASAN}

1. Tingkat Kebutuhan Suku Laut Pulau Bertam (Dilihat dari Aspek Sosial dan Budaya)

Secara historis, relasi masyarakat Suku Laut dengan alam merupakan wacana kultural yang tidak dapat dipisahkan (Chou 1997, 2010; Chou dan Wee 2002; Lenhart 2002). Beberapa puluh tahun, masyarakat Suku Laut sudah menjadi kehidupan nomadic dimana alam dianggap sebagai basis ekonomi, dikarenakan alam sebagai tempat "memproduksi dan menyediakan" segala hal bagi kelangsungan hidup mereka, sekaligus berfungsi sebagai ruang 
sosio-kultural mereka. Oleh karena itu, masyarakat Suku Laut memiliki mekanisme tertentu dalam menjaga teritori laut guna meminimalisir kerusakan lingkungan.

Menjadi berbeda ketika Orang Laut mulai tinggal di darat dan seiring dengan tumbuhnya kawasan industri di Batam (Chou dan Wee 2002). Dalam proses sejarah semacam ini, beberapa literatur menunjukkan bahwa narasi mengenai teritori laut dan darat kini berbeda dengan pengalaman Orang Laut sebelumnya (Chou 1997, 2010; Chou dan Wee 2002; Wee dan Chou 1997). Salah satunya, muncul kesadaran bahwa alam tidak selamanya menyediakan kebutuhan hidup 'secara cuma-cuma' dan tidak terbatas. Atas kesadaran tersebut, Masyarakat Suku Laut mulai bermukim secara permanen di Pulau Bertam melalui program pembangunan yang digagas oleh Departmen Sosial RI. Hidup secara permanen menyebabkan adanya perubahan hidup yang dijalani yang tentu saja sangat berbeda dengan kehidupan sebelumnya sebagai pengembara diperairan sekitar wilayah Batam.

Perubahan hidup yang dijalankan oleh masyarakat Suku Laut di Pulau Bertam tentu saja mempengaruhi kualitas hidup mereka terutama kesejahteraan sosial. Dari hasil wawancara yang dilakukan, dimensi sosial kesejahteraan hidup masyarakat Suku Laut berada pada tahap sederhana. Dari empat item pertanyaan yang dikemukakan mengenai kesejahteraan sosial, diantaranya kualitas air yang diperoleh, rumah yang ditempati keluarga, kondisi rumah yang didiami, dan peralatan ikan untuk menangkap ikan rata-rata menjawab belum cukup memadai.

Aspek budaya juga mempengaruhi perubahan hidup masyarakat Suku Laut. Hal ini terlihat dari mulai pudarnya budaya tradisi dalam hal kesenian diantaranya silat, jung, dan joget yang semula melembaga dalam kehidupan mereka sebagai media hiburan tempat mereka melepas lelah setelah berada dilautan untuk mencari tangkapan ikan. Salah satu tradisi yang masih ada pada saat ini adalah joget, namun demikian juga mengalami pergeseran dari tata cara dan peralatan yang digunakan. Jika sebelumnya Joget merupakan media hiburan gratis komunitas Suku Laut pada saat ini berubah menjadi media hiburan yang bisa mendorong mereka untuk berperilaku hidup boros. Karena kegiatan ini dilakukan rutin tiga bulan sekali dan mereka harus mengeluarkan biaya agar dapat menikmati hiburan tersebut.

Pandangan masyarakat Suku Laut mengenai konsep rumah. Di masa lalu, Orang Laut hanya mengistirahatkan sampan mereka dan menetap sementara waktu di darat ketika musim angin Utara tiba. Mereka membangun sapao (gubuk) di pulau tempat mereka singgah dan 
akan meninggalkan sapao tersebut kala musim itu berakhir (Sembiring 1993:330). Oleh karena itu, telah sedikit disinggung pada Bab II mengapa peralihan dari hidup di laut ke darat tidak semudah yang dibayangkan pemerintah. Masalah dari sisi pemerintah adalah ketika beberapa keluarga Orang Laut tetap melakukan aktivitas pengembaraan dan tinggal di laut dengan sampan selama berhari-hari bahkan sampai beberapa bulan daripada menetap di permukiman yang disedia-kan pemerintah sehingga ketika itu rumah-rumah mereka kerap kosong (Chou 2003:19; Lenhart 1997). Untuk sebagian Orang Laut yang lain, mereka dengan sukarela mengikuti anjuran pemerintah bermukim dan meninggalkan kebiasaan hidup mengelana di laut (Colchester 1986; Lenhart 1997), dan Orang Bertam adalah satu contoh kelompok Orang Laut yang sukarela bermukim dan beralih menjadi "orang pulau”.

Mengenai konsep rumah, telah banyak ahli antropologi yang membahasnya, dan antropologi mengenai 'rumah' salah satunya berangkat dari pemikiran ulang mengenai kajian-kajian kekerabatan, yang memfokus pada keterkaitan antara rumah dengan ciri khas arsitektural tertentu dan manusianya sebagai kreator dan penghuni (Thomas 2010:356). Philip Thomas (2010:354) membedakan rumah menjadi dua hal, "the house as built environment with the 'house' as a category and idea central to the conceptualization and practice of social relations." Dari definisi ini, konsepsi mengenai rumah dapat diletakkan dalam konteks sosial, ekonomi, dan kultural yang berbeda-beda, yaitu (1) rumah sebagai bangunan (fisik) dan (2) 'rumah' yang berasosiasi dengan konseptualisasi (ide) dan praktik dari relasi sosial tertentu (perilaku).

Dalam uraian di bagian selanjutnya, saya menjelaskan bahwa organisasi sosial Orang Laut memiliki ciri khas: satu rumah tangga (household) adalah juga satu keluarga batih (nuclear family), dan rumah tangga ini berada dalam lingkup satu sampan. Artinya, sampan adalah rumah sekaligus basis fundamental sosial dan kebudayaan mereka. Selain itu, sampan merepresentasikan hubungan sosial mereka yang berkenaan dengan aktivitas ekonomi dan kosmologi kelautannya (Chou 2010; Lenhart 2004). Oleh sebab itu, ketika mereka didorong pemerintah bermukim di permukiman rumah darat dan meninggalkan sampan mereka sebagai tempat tinggal, dalam arti tertentu hal ini mau tidak mau juga akan mengubah pola relasi dalam organisasi sosial mereka sekaligus persepsi Orang Laut mengenai "rumah" itu sendiri. Dengan demikian, kepemilikan rumah melambangkan proses peralihan identitas Orang Laut dari sampan ke rumah. 
2. Tingkat kesejahteraan hidup nelayan Suku Laut Pulau Bertam

Pasca-pemukiman masyarakat terasing di tahun 1980an, kehadiran negara di tengah kehidupan sehari-hari Orang Bertam yang dapat diamati ialah pada hal-hal yang berhubungan dengan program-program bantuan pemerintah. Dalam sekitar tiga bulan saya mengamati bahwa di hadapan negara, terkait dengan akses pada program bantuan pemerintah, mereka diposisikan sebagai masya-rakat miskin. Miskin dalam makna bahwa Orang Bertam tidak memiliki 'basis ekonomi' yang memadai untuk pemenuhan kebutuhan hidup minimalnya. Dalam pelabelan seperti ini, mereka justru dengan sadar terus berusaha memperoleh sesuatu dari pemerintah.

Kendati wujud program bantuan pemerintah cukup beragam dan datang dari berbagai dinas, saya hanya memfokuskan pada tiga program nasional, yaitu bantuan rumah layak huni, Bantuan Langsung Sementara Mandiri (BLSM), dan beras miskin (Raskin). Menurut pemerintah, ketiga program bantuan ini dibuat berdasar Undang-undang Nomor 11 tahun 2009 tentang Kesejahteraan Sosial dan Undang-undang Nomor 13 tahun 2011 tentang Penanganan Fakir Miskin. Kedua undang-undang ini diterjemahkan dengan rinci salah satunya ke dalam Peraturan Menteri Sosial Nomor 9 Tahun 2012 tentang Pemberdayaan Komunitas Adat Terpencil pada Bab IV mengenai Bantuan Sosial melalui Pasal 27 sampai Pasal 31.

Pasal-pasal dalam Bab IV Peraturan Menteri Sosial tersebut menyatakan bahwa sebagai upaya penanggulangan kemiskinan pemerintah memberikan jaminan sosial kepada Komunitas Adat Terpencil dan masyarakat miskin terutama dalam pemenuhan kebutuhan pokok, yang di antaranya adalah makanan pokok (khususnya beras) dan tempat tinggal (rumah) berstandar layak huni dengan salah satu cirinya harus berukuran minimal $30 \mathrm{~m} 2$ (Kemenkokesra 2012; Kementerian Sosial 2012:24-28). Sedangkan, mengenai program BLSM, kebijakan bantuan ini menurut pemerintah, yang dikeluarkan atas saran konsultan ekonomi Vikram Nehru dari Bank Dunia, merupakan kelanjutan program Bantuan Langsung Tunai (BLT) yang bergulir pada 2008 lalu sekaligus merupakan solusi atas masalah kenaikan harga pangan dan kebutuhan pokok lainnya sebagai dampak dari kenaikan harga bahan bakar minyak di pertengahan tahun 2013 yang lalu. 
3. Faktor-faktor apa yang mempengaruhi kesejahteraan hidup masyarakat Suku laut Pulau Bertam Kota Batam

\section{Faktor Ekonomi}

Pertama, umumnya Orang Laut semula tidak menuntut besaran (nilai) uang tertentu untuk mengganti kuantitas komoditas maritim yang disetor ke para tauke. Dapat disangka bahwa Orang Laut sama sekali tidak memerhitungkan ongkos lelahnya (production and distribution costs), karena mereka memilih untuk 'mengambil' beberapa bahan kebutuhan harian selama melaut, seperti gula, kopi, beras, minyak tanah, dan sebagainya. Kedua, ketika Orang Laut mulai mengenal uang. Uang yang didapat hampir tidak digunakan untuk membeli hal-hal di luar "kebutuhan dasar" mereka, seperti yang telah disebut sebelumnya, ditambah dengan kebutuhan, misalnya, memperbaiki atau membeli sampan baru, yang kala itu sampan diproduksi dan dijual oleh beberapa orang Tionghoa atau orang Melayu (lihat Chou 2003; Nimmo 1972). Ketiga, terdapat keistimewaan pada Orang Laut yang barangkali tidak dimiliki oleh kelompok nelayan dari sukubangsa lain, bahwa dengan pola hidup mengelana di laut dalam kurun waktu tertentu membuat Orang Laut dapat membedakan 138 jenis ikan yang dijumpai di perairan Kepulauan Riau, dan 40 jenis ikan di antaranya merupakan jenis ikan yang biasa dikonsumsi, termasuk di dalamnya ikan dugong (duyung, sea cow) dan penyu (Chou 2010:83).

Sistem klasifikasi mengenai jenis-jenis ikan ini menarik, dan tentu saja, meski tidak berlaku pada semua jenis ikan, mereka memiliki penamaan tersendiri atas ikan-ikan tersebut. Hanya sayang, dari sejumlah pustaka, tidak muncul informasi yang menunjukkan perbandingan pengetahuan mereka tentang biota laut ini dengan nelayan yang non-Orang Laut, sebab hanya dengan menunjukkan perbandingan semacam itu, kita dapat mengetahui dengan persis apakah Orang Suku Laut dapat dilihat sebagai kelompok nelayan yang "lebih mumpuni" dibandingkan dengan mereka yang bukan kelompok pengembara. Keempat, dari ketiga kemungkinan di atas, saya kira fakta bahwa Orang Suku Laut menganggap aktivitas kenelayanan merupakan sesuatu yang inheren dalam kehidupan (baca: kebudayaan) mereka sehingga hampir tidak mungkin dipisahkan, bahkan dilepaskan, dari komunitas ini.

Pasca pemukiman, dalam perspektif tertentu pula, setiap individu Orang Bertam dapat dipandang sebagai 'pekerja' yang tidak terikat oleh 'institusi' kultural manapun sebagaimana di masa lalu yang mengikat mereka dengan aturan-aturan dan nilai-nilai tertentu (Parry 2005:146). Status semacam ini muncul manakala mereka menghadapi kenyataan bahwa laut 
sebagai "basis ekonomi tak terbatas" (unlimited base) (Gudeman 2005:98) tidak lagi mencukupi kebutuhan mendasar mereka untuk bertahan hidup. Oleh karena itu, mereka melakukan pekerjaan-pekerjaan lain, baik yang berbasis laut maupun darat. Di sisi lain, kita perlu menyadari bahwa perubahan ini juga merupakan konsekuensi dari peren-canaan kawasan (mapping) pembangunan ekonomi multinasional (Indonesia-Malaysia-Singapore Growth Triangle) yang dijalankan pemerintah di awal 1990-an, dengan mematok teritorial (laut dan darat) tertentu tanpa mempertimbangkan keberadaan atau kehidupan (basis ekonomi) Orang Laut yang berada di dalam teritori tersebut (Chou 2010; Chou dan Wee 2002; cf. Li 2013).

Konsekuensi atas ketersingkiran dari basis ekonominya itu membuat mereka perlu mencari pekerjaan lain. Dalam bahasa lain, mereka mengalami ketersingkiran untuk kali kedua. Pertumbuhan industri yang pesat di kawasan Batam dan sekitarnya, yang bertujuan untuk memacu pertumbuhan ekonomi dan peningkatan kesejahteraan masyarakat, nyatanya tidak memungkinkan untuk menyerap sumber daya manusia yang berasal dari komunitas pengembara laut ini (dan juga sebagian besar orang lokal selain Orang Laut di Kepri) (Chou dan Wee 2002). Hal ini disebabkan oleh keterampilan mereka yang tidak sesuai dengan prasyarat sebagai pekerja (buruh) pabrik. Oleh karena mengalami dua kali ketersingkiran inilah mereka lantas mengupayakan hal lain, agar tetap menghasilkan uang (pendapatan) selain dari aktivitas melautnya yang serba terbatas. Dari fakta semacam ini, saya berpandangan bahwa masuk akal bila sebagian besar dari Orang Bertam tidak hanya bekerja sebagai nelayan, tetapi juga bekerja dalam dua area sekaligus: yaitu kerja laut dan kerja darat.

Dari situ, dapat dikatakan bahwa mayoritas Orang Bertam saat ini bekerja di domain darat dan laut. Fakta ini juga perlu dilihat bahwa tidak lagi relevan dengan isu menetap dan tidak menetap pada Orang Bertam, karena sudah tidak ada lagi Orang Bertam yang menjalani pola hidup mengembara dan menetap sementara. Berdasarkan hasil wawancara yang dilakukan bahwa Masyarakat Suku Laut yang mayoritas menjadi nelayan merasa pendapatan bulanan yang diperoleh dari hasil menangkap ikan tidak mencukupi untuk kebutuhan hidup. Beberapa nelayan memasarkan sendiri hasil tangkapan mereka dijual pada harga pasaran, agar mendapatkan keuntungan yang besar dibandingkan mereka menjual kepada toke. Bagi nelayan Suku Laut, pendapatan yang mereka peroleh tidak mencukupi untuk kebutuhan hidup sehari-hari maka mereka melakukan pekerjaan sampingan. Dengan demikian, kombinasi antara kerja laut dan darat, atau pada kerja darat saja, dapat dimaknai sebagai mata 
pencaharian yang mereka jalankan untuk memperoleh pendapatan lain di luar aktivitas kenelayanannya sebagai konsekuensi dari pembangunan ekonomi semasa Orde Baru di mana keberpihakan negara justru pada kaum bermodal besar (Mubyarto 1997).

\section{Tingkat Pemahaman Pemerintah}

Sejarah bermukimnya Orang Laut di Bertam menarik untuk didiskusikan lebih jauh. Bukan soal kegagalan para perencana program membangun 100 rumah hunian, melainkan lebih pada ketidakpahaman pemerintah pada elemen budaya organisasi sosial Orang Laut. Ketidakmengertian pemerintah ini menyebabkan dalam proses memukimkan kelompok Orang Laut di beberapa pulau ternyata justru, “.. members of rival Orang Laut groups have been resettled on the sameisland" (Chou 2010:138). Saya kira pemerintah tidak pernah membayangkan bahwa hal ini dalam perjalanannya membawa implikasi sosial dan kultural dalam kehidupan Orang Laut. Pemerintah tidak pernah menyadari bahwa ratusan Orang Laut yang tersebar di Kepri "tidak tunggal", homogen, dan di antara mereka terdapat suatu kelompok-kelompok yang berbeda. Oleh sebab itu, kebijakan pemukiman OSL di akhir 1980an sampai 1990an justru membuat komunitas OSL terjerat ke dalam persoalan-persoalan sosial baru.

\section{KESIMPULAN}

Tahap kesejahteraan hidup masyarakat Suku Laut berada pada tahap belum sejahtera. Kehidupan masyarakat Suku Laut berada pada tahap kurang sejahtera dan tidak memuaskan karena kekurangan faktor - faktor yang mendorong kearah pembangunan kesejahteraan hidup diantaranya kondisi rumah yang ditempati, teknologi peralatan yang digunakan untuk menangkap ikan serta kualitas air yang digunakan untuk kebutuhan sehari-hari. Dari segi budaya, beberapa budaya masyarakat Suku Laut memulai memudar seiring dengan perubahan hidup mereka yang menetap permanen didaratan Pulau Bertam.

Faktor ekonomi dan tingkat pemahaman pemerintah merupakan faktor - faktor yang mempengaruhi tingkat kesejahteraan masyarakat Suku Laut. Pada faktor ekonomi, masyarakat Suku Laut merubah pandangan mereka domain pekerjaan di darat dan dilaut guna memenuhi kebutuhan hidup mereka. Faktor tingkat pemahaman pemerintahan masih rendah terutama terhadap elemen budaya organisasi sosial Orang Laut, sehingga melahirkan persoalan-persoalan sosial kedepannya. 
Pihak pemerintah memainkan peranan yang penting dalam meningkatkan kesejahteraan hidup masyarakat Suku Laut dengan berbagai program dan bantuan. Namun, berbagai program dan bantuan yang berikan pemerintah kepada masyarakat Suku Laut justru membuat mereka menjadi ketergantungan. Sifat ketergantungan muncul diakibatkan karena pemerintah dalam membuat program cenderung memanjakan warga dengan bantuan yang bersifat amal (charity). Program-program yang bersifat insidental (one shot programme) ataupun amal (charity) merupakan program yang kurang dapat dilihat manfaatnya dalam jangka panjang, sebagaimana yang diungkap oleh Adi (2008). Ketergantungan sendiri bukanlah merupakan tujuan dari sebuah kebijakan publik sebagaimana pendapat Nugroho (2006: 22) bahwa kebijakan publik yang terbaik adalah mendorong setiap warga masyarakat untuk membangun daya saing masing-masing, dan bukan semakin menjerumuskannya ke dalam pola ketergantungan.

\section{DAFTAR PUSTAKA}

Ardiansyah, Agus Deddy. (2007). Implementasi Program Pemberdayaan Ekonomi Masyarakat Pesisir Di Kota Pangkal Pinang. Skripsi. Universitas Sriwijaya. Palembang.

Badrudin, Rudy. (2012). Ekonomika Otonomi Daerah. Yogyakarta: UPP STIM YKPN.

Swasono. 2005. Indonesia dan Doktrin Kesejahteraan Sosial Dari Klasikal Dan Neoklasikal Sampai ke The End Of Laissez-Faire. Perkumpulan Prakasa. Jakarta.

Situmorang, Husni Cahzali. (2017). Kebijakan Pemerintah kaitannya Dengan Kesejahteraan. Jurnal Social Security. Depok. Yayasan pengembangan Jaminan Sosial. Depok.

Magrabi, F.M \& Y.S. Chung, S.S. Cha, S.J. Yang. (1991). The Economics of Household Consumption. New York: Praeger Publishers.

Zastrow, Charles. (2000). Introduction to Social Work and Social Welfare. United States: Brooks. Cole.

Embong, Abdul Rahman. (2005). Development and Well being. Selangor D.G., Malaysia: Malindo Printers SDN BHD.

Albert, M \& Hahnel, R. (2005). Traditional Welfare Theory. dalam www.zmag.org/books/1/html .diakses pada 18 Agustus 2018.

Sembiring, S. (1993). Orang Laut di wilayah Kepulauan Riau-Lingga. Dalam Koentjaraningrat (ed.). Masyarakat terasing di Indonesia (pp.323-343). Jakarta: Gramedia Pustaka Utama. 
Chou, C. (1997). Contesting the tenure of territoriality: the Orang Suku Laut. Dalam Bijdragen tot de Taal-, Land- en Volkendkunde, Riau in Transition, 153,(4), 605629 , Leiden.

Chou, C. (2010). The Orang Suku Laut of Riau, Indonesia: the inalienable gift of territory. London: Routledge.

Chou, C. \& Wee, V. (2002). Tribality and globalization: the Orang Suku Laut and the "growth triangle" in a contested environment. Dalam G. Benjamin \& C. Chou (eds.), Tribal communities in the Malay world: historical, cultural and social perspectives (pp.318-363). Singapore: Institute of Southeast Asian Studies.

Colchester, M. (1986). Unity and diversity: Indonesian policy towards tribal peoples. The Ecologist, 16 (2/3), 89-98.

Thomas, P. (2010). House. Dalam Alan Barnard \& Jonathan Spencer (eds.), Encyclopedia of social and cultural anthropology, - 2ndedition (pp. 353-357). Routledge.

Mubyarto. (1997). Riau: progress and poverty. Bijdragen tot de Taal-, Land- en Volkendkunde. Riau in Transition, 153, (4), 542-556. Leiden.

Profil Kecamatan Belakang Padang. 2017.

Profil Kota Batam . 2017 